\title{
Shore-based competitive recreational fisheries in southern Bahia, Brazil: a baseline study
}

\author{
Kátia Meirelles Felizola Freire ${ }^{1,2, ~ *}$, Felipe Pinto Nascimento ${ }^{2,3}$ and Gecely Rodrigues Alves Rocha ${ }^{2}$ \\ ${ }^{1}$ Departamento de Engenharia de Pesca e Aquicultura, Universidade Federal de Sergipe, Cidade Universitária Prof. José Aloísio de Campos, \\ Av. Mal. Rondon s/n, Jardim Rosa Elze - São Cristóvão, Brazil. ${ }^{2}$ Universidade Estadual de Santa Cruz, Campus Soane Nazaré de Andrade, \\ Rodovia Jorge Amado, km 16, Salobrinho - Ilhéus, Brazil. ${ }^{3}$ Instituto do Meio Ambiente e Recursos Hídricos (INEMA), Avenida Luís Viana \\ Filho, $6^{\text {a }}$ Avenida, $n^{\circ}$ 600, CA - Salvador, Brazil
}

Marine and Fishery Sciences MAFIS

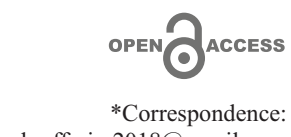

kmffreire2018@gmail.com

Received: 1 June 2020 Accepted: 8 July 2020

ISSN 2683-7595 (print) ISSN 2683-7951 (online)

https://ojs.inidep.edu.ar

Journal of the Instituto Nacional de Investigación y Desarrollo Pesquero (INIDEP)

This work is licensed under a Creative Commons AttributionNonCommercial-ShareAlike 4.0 International License

\begin{abstract}
This study describes shore-based competitive fishing events in Ilhéus, southern Bahia (Brazil), including catch composition, and provides information on the profile of recreational fishers participating in these events. Information was collected in all events promoted by the Clube de Pesca de Ilhéus (CLUPESIL) in 2007-2008. A total of 26 competitive fishing events were organized during this period, with 47 species caught. The top species were: Cathorops spixii, Menticirrhus littoralis, Trachinotus goodei, Eucinostomus melanopterus, Polydactylus virginicus, Atherinella brasiliensis, and Eucinostomus argenteus. These seven species represented $87 \%$ of the total catch in number and $78 \%$ in weight. Menticirrhus littoralis and Polydactylus virginicus are species of commercial interest and their catch was dominated by juveniles. Local recreational fishers were predominately middle-aged men, who tended to use small hooks and mainly shrimp as bait. They were consumption-oriented, but also released small fishes. During competitions, fishers used even smaller hooks. Most of them perceived shrimp trawling as the main factor affecting recreational fisheries. The use of larger hooks and a minimum fish size of $20 \mathrm{~cm}$ are suggested to decrease the capture of juveniles, mainly those species of commercial importance. This study sets a baseline from which new studies can be proposed to access the current status of local recreational fisheries.
\end{abstract}

Key words: Angling, recreational fishery, sport fishing, shore-based fisheries, tournament, northeastern Brazil.

Pesca recreativa competitiva desde la costa en el sur de Bahía, Brasil: un estudio de línea de base

RESUMEN. Este estudio describe eventos competitivos de pesca desde la costa en Ilhéus, sur de Bahía (Brasil), incluida la composición de la captura, y proporciona información sobre el perfil de los pescadores recreativos que participan en estos eventos. La información se recopiló en todos los eventos promovidos por el Clube de Pesca de Ilhéus (CLUPESIL) en 2007-2008. Se organizaron un total de 26 eventos de pesca competitiva durante este período con 47 especies capturadas. Las principales especies fueron: Cathorops spixii, Menticirrhus littoralis, Trachinotus goodei, Eucinostomus melanopterus, Polydactylus virginicus, Atherinella brasiliensis y Eucinostomus argenteus. Estas siete especies representaron el $87 \%$ de la captura total en número y el $78 \%$ en peso. Menticirrhus littoralis y Polydactylus virginicus son especies de interés comercial y su captura estuvo dominada por juveniles. Los pescadores recreativos locales eran predominantemente hombres de mediana edad, que solían usar anzuelos pequeños y principalmente camarones como carnada. Estaban orientados al consumo, pero también liberaron peces pequeños. Durante las competiciones, los pescadores usaron anzuelos incluso más pequeños. La mayoría de ellos percibió a el arrastre de 
camarones como el principal factor que afecta la pesca recreativa. Se sugiere el uso de anzuelos más grandes y un tamaño mínimo de $20 \mathrm{~cm}$ para disminuir la captura de juveniles, principalmente los de especies de importancia comercial. Este estudio establece una línea de base a partir de la cual se pueden proponer nuevos estudios para acceder al estado actual de la pesca recreativa local.

Palabras clave: Pesca con caña, pesca recreativa, pesca deportiva, pesca desde la costa, torneo, noreste de Brasil.

\section{INTRODUCTION}

Recreational fisheries have been recognized worldwide as an important industry, which generates about 39.7 billion USD in expenditure for marine waters only (Cisneros-Montemayor and Sumaila 2010). Some rough global estimates available indicated that recreational catches amounted to about 0.5-11 million tonnes, including only inland fisheries, only marine fisheries or both (Coates 1995; Cooke and Cowx 2004), which are small in relation to commercial catches (FAO 2018). Only recently, catches originating from marine recreational fisheries were estimated in a per country basis using several different approaches depending on local data availability, indicating that around 0.9 million tonnes were extracted from marine waters by recreational fishers in 2014 (Freire et al. 2020). Even though recreational catches are globally small, they may surpass commercial catches for some species (Gentner and Lowther 2002; Coleman et al. 2004; Freire et al. 2020). Global number of anglers is also unknown, but Arlinghaus et al. (2020) revised all participation rates available around the globe indicating a global participation rate of $10.6 \%$ and increasing up to $42 \%$ in countries such as Norway. For developing countries as a whole, these estimates are unavailable. According to Arlinghaus et al. (2020), participation rate is unknown for regions such as Central America, the Caribbean, Africa, and Southeast, Central and Western Asia. For South America, participation rate is $0-5 \%$ and has been increasing in the last years. In Brazil, this proportion may be slightly lower than 1\% (Freire et al. 2016).
A comprehensive analysis of recreational fisheries requires the understanding of their different sectors: shore-based, boat-based (both coastal and oceanic), spearfishing, participants of competitive fishing events (tournaments, championships, jamborees), and freshwater and marine fisheries. Each sector has different consumption habits and motivation factors, which result in a range of fishing practices (Fedler and Ditton 1994). Ultimately, these choices will be reflected in fishing policies. The importance of competitive events has been underestimated, even though their frequency in some regions is very high. In North America, e.g., about 25,000 events were promoted in 2000-2001 in freshwater and another 978 in marine waters (Kerr and Kamke 2003). Some of them may have up to 3,000 participants (Schramm Jr. et al. 1991), which could have a considerable high impact on the abundance of target species, especially when targeting single species. In Brazil, there is no estimate of the total number of events, but Freire (2010) reported a total of 100 promoted annually in marine waters only in northeastern Brazil.

Llompart et al. (2012) emphasized that most of the studies on marine recreational fisheries have been carried out in the Northern Hemisphere with a few studies in the Southern Hemisphere, including Australia, New Zealand, and South Africa. Information about recreational fisheries in South America (including Brazil) is also scarce and, in some cases, restricted to a few oceanic fishing tournaments (see, e.g., Mourato et al. 2016; Mourato et al. 2019). This is equally true for cold temperate marine waters in South America, where Llompart et al. (2012) claimed to have analysed for the first time the major coastal recreational fishery. In northeastern Brazil, a typically tropical 
area, the availability of studies is also scarce (see, e.g., Nunes et al. 2012; Freire et al. 2017). In this region, recreational fishers are organized in fishing clubs and prefer shore-based fishing activities (Freire 2005), even though offshore recreational fisheries have been gaining many adepts throughout the years (Freire et al. 2018). Some clubs are very active in promoting fishing tournaments all year around, but do not record their catch by species. Therefore, there is a lack of knowledge about catch composition. One of these fishing clubs, CLUPESIL (Clube de Pesca de Ilhéus), is located in southern Bahia (Municipality of Ilhéus) and has been very active in promoting competitive fishing events since 1975 when it was established. The objective of this study was to describe competitive fishing events taking place in Ilhéus, southern Bahia, including the catch composition, and to provide information on the profile of recreational fishers participating in these events to serve as a baseline to assess changes to current state and future perspectives.

\section{MATERIALS AND METHODS}

\section{Competitive fishing events and ichthyofauna}

All competitive fishing events promoted by the Ilhéus Fishing Club (Clube de Pesca de Ilhéus CLUPESIL) within the limits of the municipality of Ilhéus (about $32 \mathrm{~km}$ to the north and $33 \mathrm{~km}$ to the south) were monitored in 2007-2008 (Figure 1). Three other fishing clubs existed in Ilhéus during that period: Candirú Clube de Pesca, Clube de Pesca da Gabriela, and Estrela do Mar. However, none of them promoted fishing competitions.

CLUPESIL organized one to three competitive fishing events per month in Ilhéus, with a total of 26 events in 2007-2008 (Table 1). Fishers from the other three local clubs participated in these events. Some events were two days long (four hours on Saturday afternoon and four hours on
Sunday morning), such as Torneio da Gabriela, which attracted fishers from other states (Alagoas, Sergipe, Espírito Santo, and Rio de Janeiro), totaling 168 fishers in 2007 and 96 in 2008. All the others were one-day events, lasting four hours (Saturday afternoon or Sunday morning), and all participants inhabited Ilhéus or the surroudings. An average of 40 fishers took part in the CLUPESIL Internal Championship (Campeonato Individual de Pesca de Arremesso de Praia do CLUPESIL) in 2007, starting with 48 fishers and finishing with 32 by the end of the year. In 2008, 54 fishers were present in the first round, but only 38 participated in the last round. In order to account for differences in effort among events, number and weight of fishes caught were divided by number of fishers before the analysis of temporal trends.

After each event, the organizers recorded the results as total number of fishes caught per recreational fisher and their corresponding total weight. These data were used to calculate the mean fish weight throughout the study period. Our research team then separated each specimen by common name in buckets. The identification of specimens by common name was done by an 'expert' fisher nominated by the participants based on his long term experience. The content of each bucket was then counted, weighed, and recorded by common name. Between one and three specimens associated with each common name were taken to the Laboratório de Oceanografia Biológica at the Universidade Estadual de Santa Cruz to be identified by their scientific names mainly according to Figueiredo and Menezes $(1978,1980,2000)$ and Menezes and Figueiredo (1980, 1985). The total number and weight of each species caught were calculated based on the results of the competitive events. Species found in $75-100 \%$ of competitive events were considered 'highly frequent', in 50$74 \%$ were 'frequent', and 'occasional' if found in less than $50 \%$ of the events. Catch per unit of effort (CPUE) was calculated both in number and weight of fish per recreational fisher. 


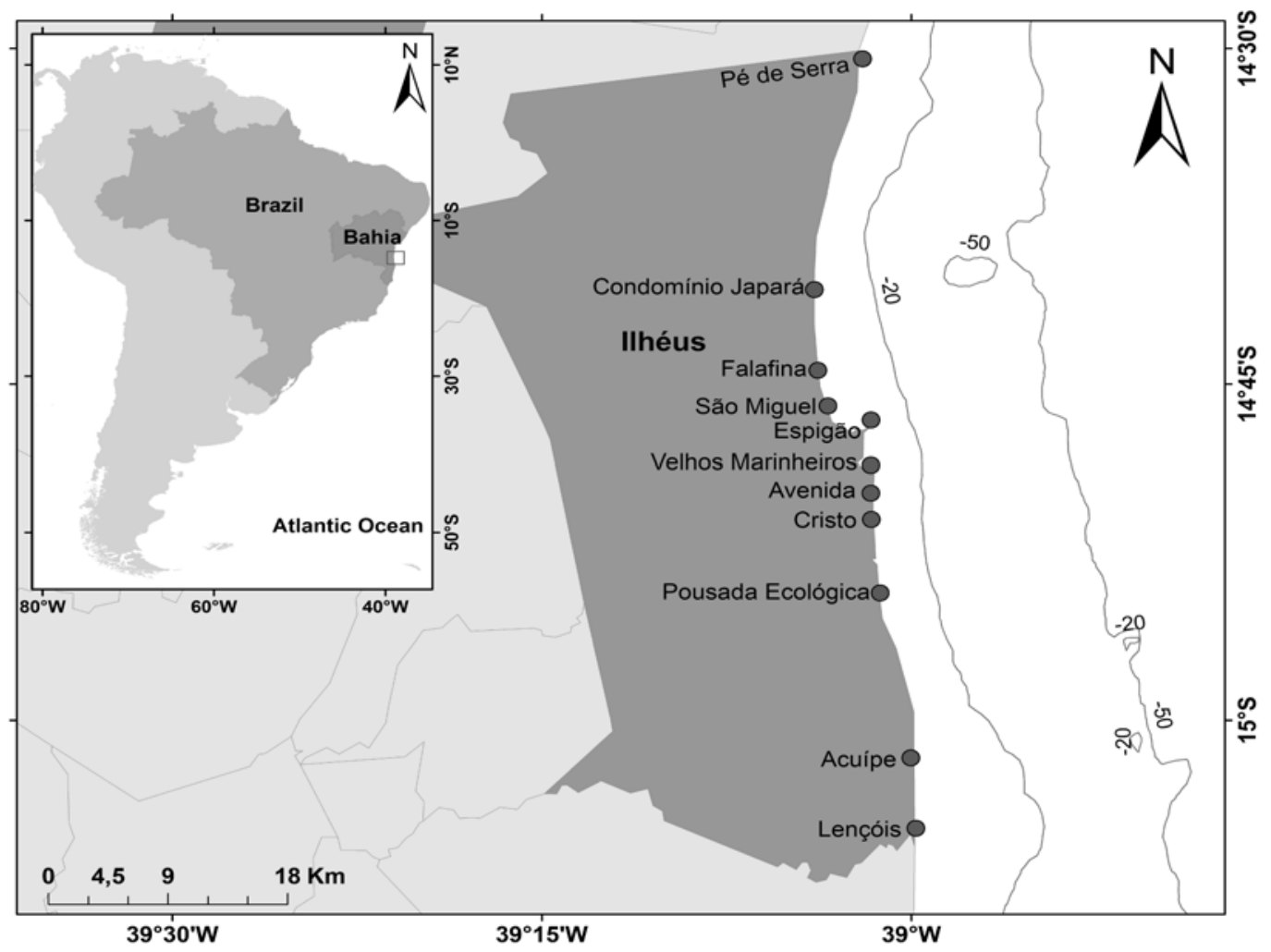

Figure 1. Beaches where competitive fishing events promoted by CLUPESIL occurred in Ilhéus, southern Bahia, Brazil (20072008). Downtown Ilhéus corresponds to Espigão, Velhos Marinheiros, Avenida, and Cristo. Pé de Serra to São Miguel are northern beaches and Pousada Ecológica to Lençóis are southern beaches.

Additionally, samples of at least 30 specimens of each main species (unless a smaller number was caught) were taken from each event after being counted and weighed by the organizers, and carried to the laboratory to be individually measured (total length; $\mathrm{cm}$ ), weighed (total weight; g) and sexed, and had their maturity stage defined based on a macroscopic analysis. A simple four stage scale of maturity was used (Vazzoler 1996): I - immature; II - developing; III - ripe; IV - post-spawning. Only detailed information for Menticirrhus littoralis (Holbrook, 1847) and Polydactylus virginicus (Linnaeus, 1758) were presented due to the availability of size at first maturity from the literature (Braun and Fontoura 2004) or the collection of sufficient data to fit a maturity curve (using the proportion of stages II, III and IV), allowing for the estimation of the proportion of juveniles in the catch. These species are caught by commercial fisheries and were also captured by recreational fishers in the neighbor state of Sergipe, the only state in northeastern Brazil where catch composition in fishing competitive events was provided by species (Freire et al. 2017). A t-test considering equal variances was applied to compare the mean size between 2007 and 2008 for these two species.

Association among fishing grounds (beaches) was assessed using cluster analysis after transforming the abundance data using square root to decrease the weight of very abundant species (Krebs 1999) and calculating the Bray-Curtis similarity index. 


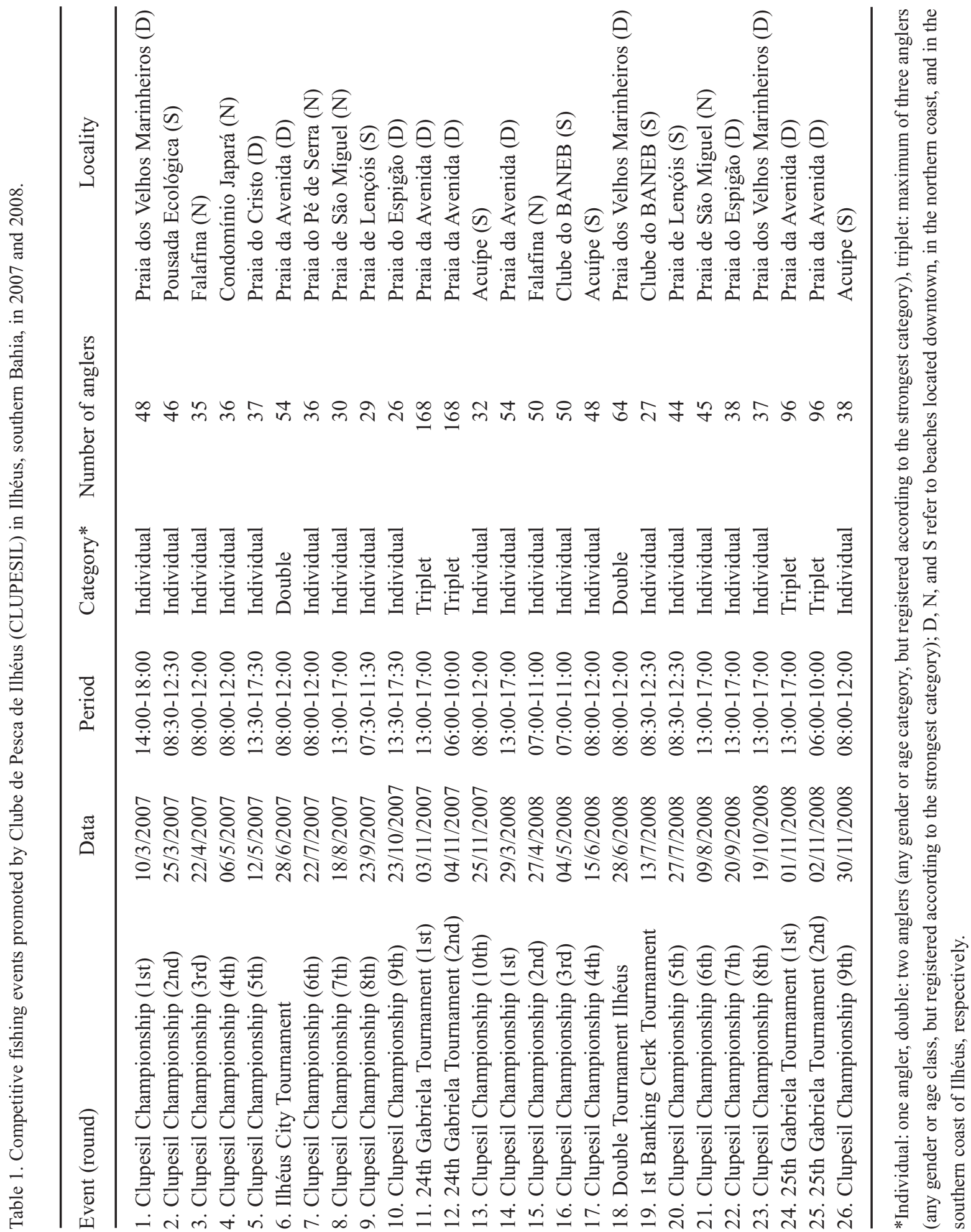




\section{Profile of recreational fishers}

A questionnaire with 22 open- and close-ended questions was applied in 2008 to recreational fishers that participated actively in the CLUPESIL Internal Championship. As previously mentioned, a maximum of 54 fishers were present at the beginning of this championship (March 2008), but numbers decreased throughout the year and some fishers may have missed some of the rounds. The questionnaire was personally applied to fishers by one of the authors right after each of the rounds in an attempt to include all fishers. No fisher refused to participate in this study. The questionnaire included socio-economic questions related to gender, age, profession, and wages. Wages were defined in intervals $(1,2-5,6-10,11-20,>20)$ and represented the number of minimum wages earned by month per fisher ( $\mathrm{R} \$ 415.00$ in $2008 \approx$ USD 226.00). Questions also included details on fishing habits and gears, including gear type, line thickness, and hook size. Hook size was defined as the commercial standard locally used $(3 / 0,2 / 0$, $1 / 0,1,2,4,6,8,10,12,14$, and 24). An aluminum plate with each of these hooks glued on its top was shown during the interview. In order to evaluate fishing activities outside competitive events, other questions were added: preferred fishing ground, preferred time of the year and days of the week for fishing, catch-and-release practice, destination of fishes caught, origin of fishing knowledge, and fishing mates. Finally, fishers were asked about the number of years of fishing experience and which problems have affected recreational fisheries during this period.

\section{RESULTS}

\section{Competitive fishing events and ichthyofauna}

A total of 10,026 fishes (about $360 \mathrm{~kg}$ ) were caught in all competitive fishing events that took place in Ilhéus in 2007-2008. Each fisher caught an average of eight fishes per event. They usually caught between three and 11 fishes, but they caught a maximum of 17 and 19 in March and May, respectively (Figure $2 \mathrm{~A}$ ), all of them in downtown Ilhéus. Mean catch in weight per fisher was $260 \mathrm{~g}$ (138-430 g; Figure 2 B). In general, an increase in mean weight per fish was observed throughout the studied period (Figure 3). Each specimen had a mean weight of $39 \mathrm{~g}$, with two events showing lower mean weight than the trend observed (9 and $20 \mathrm{~g}$; Figure 3), both of them in downtown Ilhéus. The highest mean weight per fish (80 g) occurred in southern Ilhéus, which was above the general trend (Figure 3 ).

Based on the analysis of all specimens caught, we were able to identify fishes as belonging to 47 species and 22 families. Families with the highest number of species were: Carangidae ( 9 species), Sciaenidae (6), Haemulidae (5), Gerreidae (4), Ariidae (3), Engraulidae (3), and Centropomidae (2) (Table 2). Among the most representative families, Ariidae was the most important (about 37\% for both number and weight), followed by Carangidae, Gerreidae, Sciaenidae, Polynemidae, Atherinopsidae, Haemulidae, and Centropomidae. No species was present in all events. The following species were relevant, representing altogether $87 \%$ of the total catch in number and $78 \%$ in weight: Cathorops spixii (Agassiz, 1829), Menticirrhus littoralis, Trachinotus goodei Jordan and Evermann, 1896, Eucinostomus melanopterus (Bleeker, 1863), Polydactylus virginicus, Atherinella brasiliensis (Quoy and Gaimard, 1825), and Eucinostomus argenteus Baird and Girard, 1855. These species, together with Trachinotus carolinus (Linnaeus, 1766), Genidens genidens (Cuvier, 1829), and Caranx hippos (Linnaeus, 1766), were considered highly frequent or frequent, occurring in $50 \%$ or more of all fishing events. The remaining species had a frequency of occurrence lower than 50\% and were considered occasional (Table 2). 

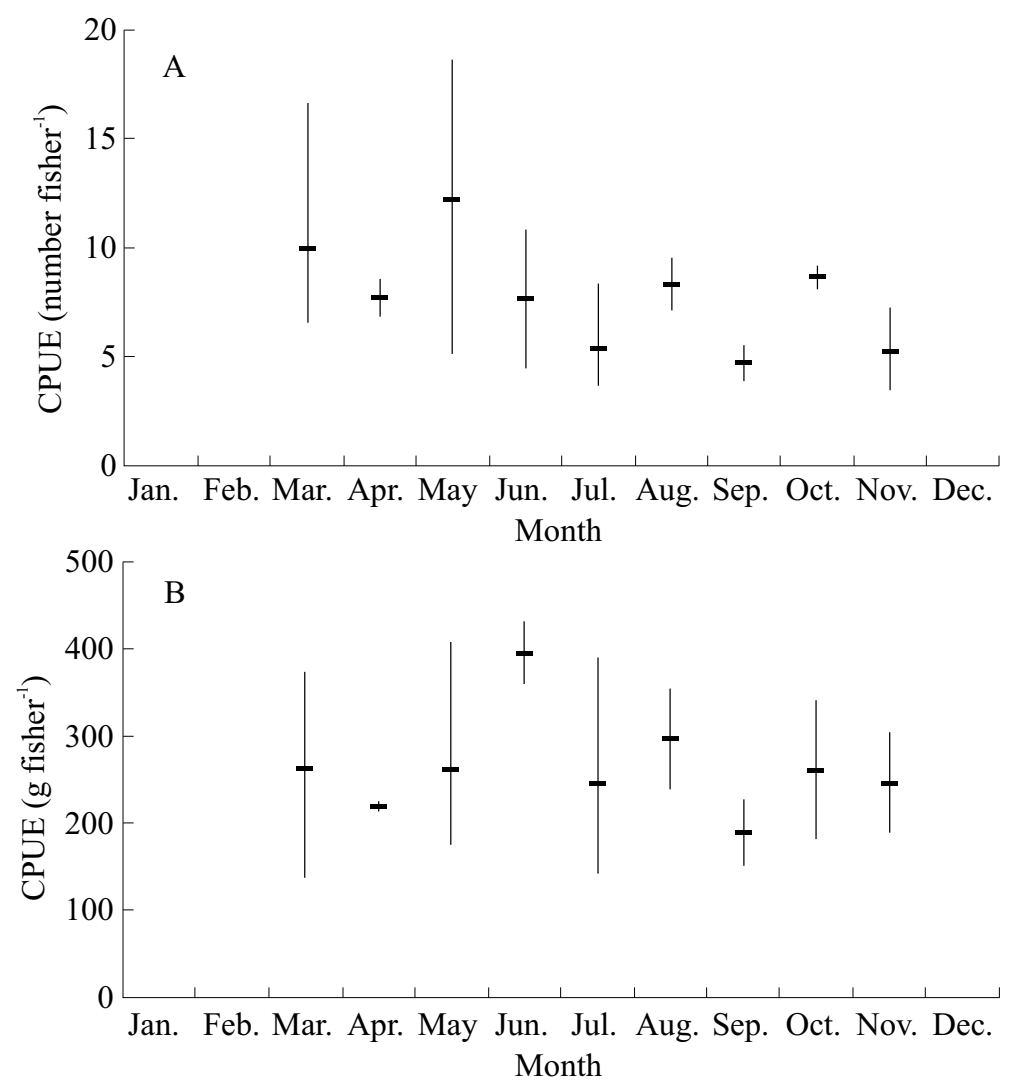

Figure 2. Number (A) and weight in grams (B) of fishes caught per recreational fisher in each competitive fishing event promoted by CLUPESIL in Ilhéus, southern Bahia (2007-2008). Vertical lines represent minimum and maximum values and horizontal lines indicate mean values for each month.

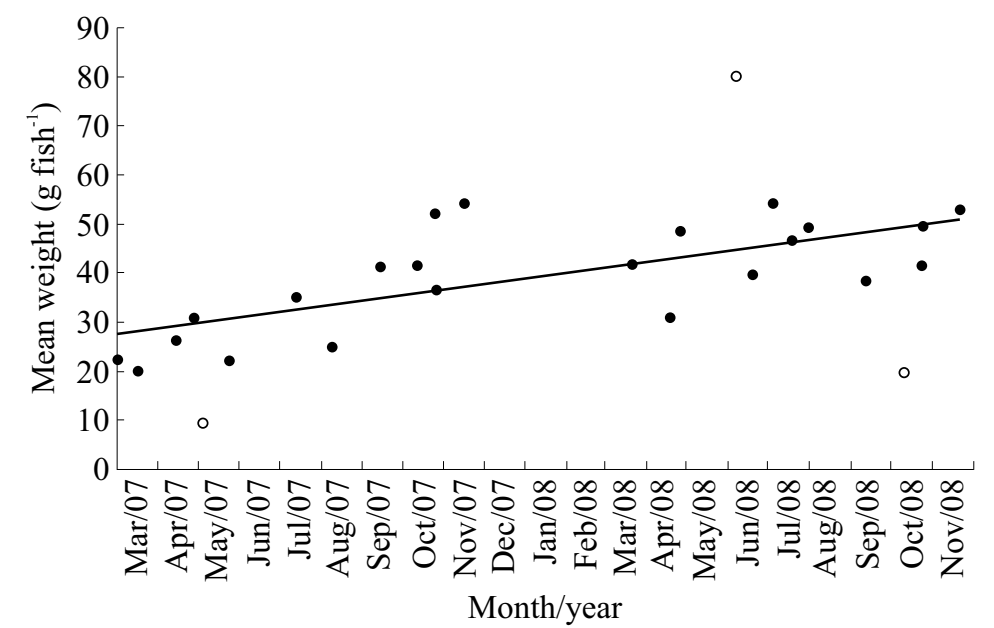

Figure 3. Mean weight of individual fishes caught by recreational fishers during competitive fishing events promoted by CLUPESIL in Ilhéus, southern Bahia (2007-2008; females and males combined). White circles represent outliers. 


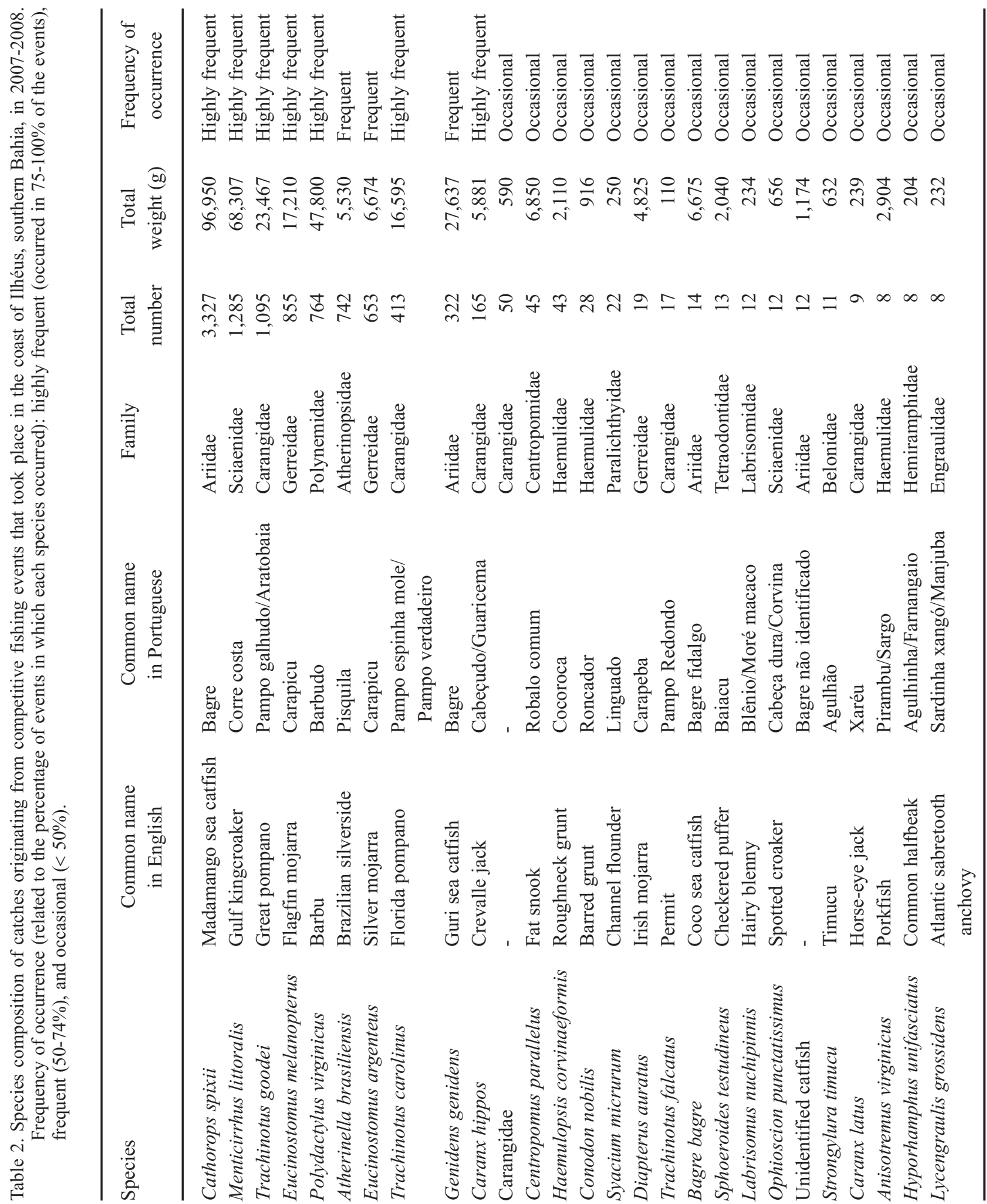




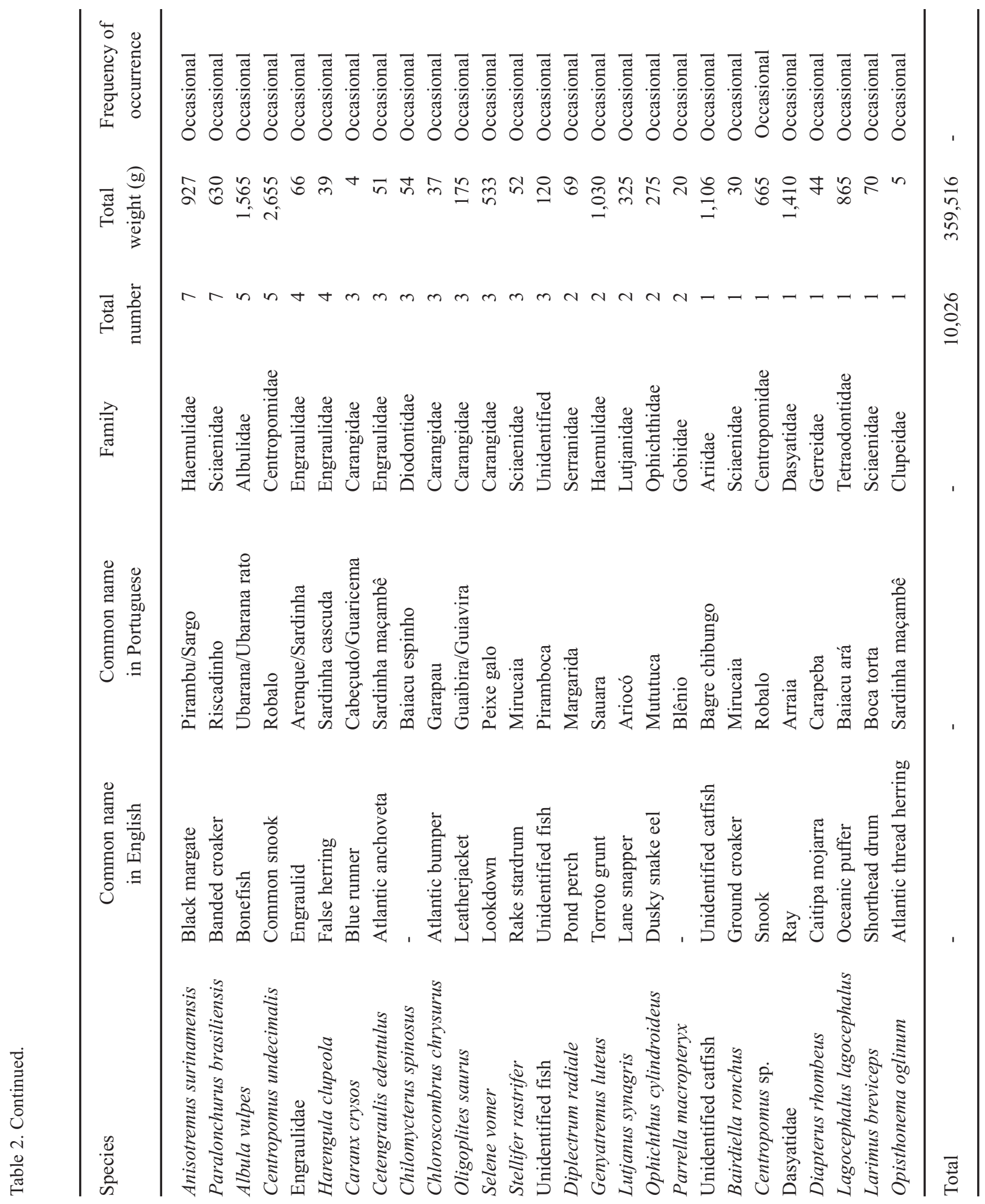


We present here detailed information for two highly frequent species, $M$. littoralis and $P$. virginicus, which were also studied in the state of Sergipe, for comparison purposes. Frequency distribution of total length for $M$. littoralis indicated that $86 \%$ of the specimens were below the maturity size available in the literature (Figure 4). It was not possible to estimate the maturity curve for this species using our local data. There was no statistically significant difference in mean total length between 2007 and 2008 for M. littoralis $(\mathrm{t}=$ $0.969 ; \mathrm{p}=0.33$ ). Size at first maturity estimated in this study for females $P$. virginicus was $22.1 \mathrm{~cm}$ TL (Figure 5). A proportion of $80 \%$ of the sampled specimens were below the maturity size (Figure 6). Similarly, no statistically significant difference was observed in mean total length between 2007 and 2008 for $P$. virginicus $(\mathrm{t}=0.089 ; \mathrm{p}=0.93)$.

Cluster analysis grouped sampling sites into three groups independently of the time of the year: one group made up of beaches located in southern Ilhéus (Praia de Acuípe and Praia de Lençóis); one group of beaches in northern Ilhéus (Condomínio Japará, Pé da Serra, and Falafina); and one final group of beaches located downtown (Praia do Espigão, Praia da Avenida, and Praia dos Milionários) (Figure 7). Even though Praia de
São Miguel is not properly located in downtown Ilheús, it presented similar catch composition. These three groups had in common a high number of C. spixii, M. littoralis, and T. goodei. However, $C$. spixii was more abundant downtown and T. goodei in the north. Menticirrhus littoralis was equally abundant in events occurring along the entire coast. Additional differences were a high predominance of E. melanopterus downtown and $P$. virginicus in the south. Praia do Cristo was included in a separated group as it was characterized by the dominance of E. argenteus, followed by $A$. brasiliensis, in an estuarine area.

\section{Profile of the recreational fishers}

A total of 57 recreational fishers were interviewed during the CLUPESIL Championship and thus included most of the active members of this fishing club at that time, as the club had 54 and 67 active members in 2007 and 2008, respectively. Currently, CLUPESIL has 60 active members. Most of these fishers were men (75\%) and their age ranged between 7 and 70 years, with the majority of them being 36-54 years old (46\%) (Figure 8$)$. Most of the fishers were vendors (12 fishers), students (9), retired

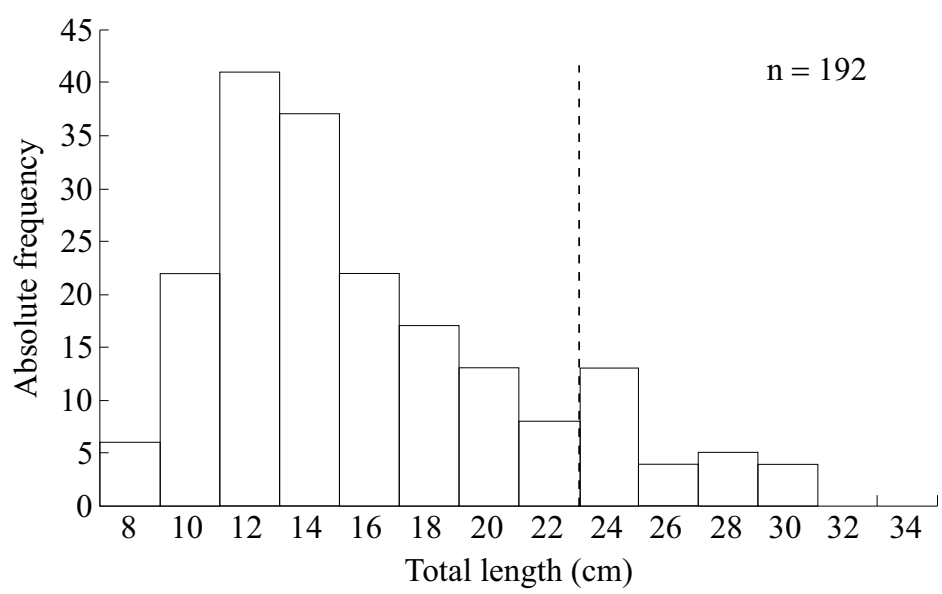

Figure 4. Frequency distribution of total length for Menticirrhus littoralis caught in competitive fishing events promoted by CLUPESIL in Ilhéus, southern Bahia (2007-2008). Dashed vertical line indicates mean size at first maturity (Braun and Fontoura 2004). 


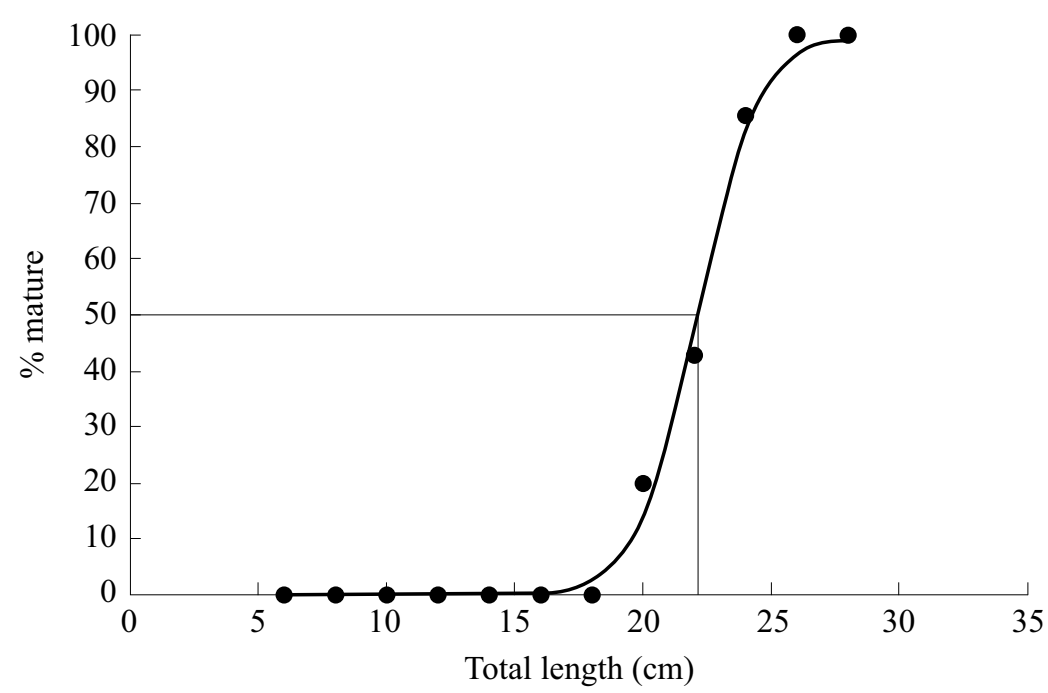

Figure 5. Mean size at first maturity for Polydactylus virginicus $\left(\mathrm{TL}_{\mathrm{m}}=22.1 \mathrm{~cm}\right)$ estimated on specimens caught in competitive fishing events in Ilhéus, southern Bahia (2007-2008). \% mature includes maturity stages: II - developing, III - ripe, and IV - post-spawning (Vazzoler 2006).

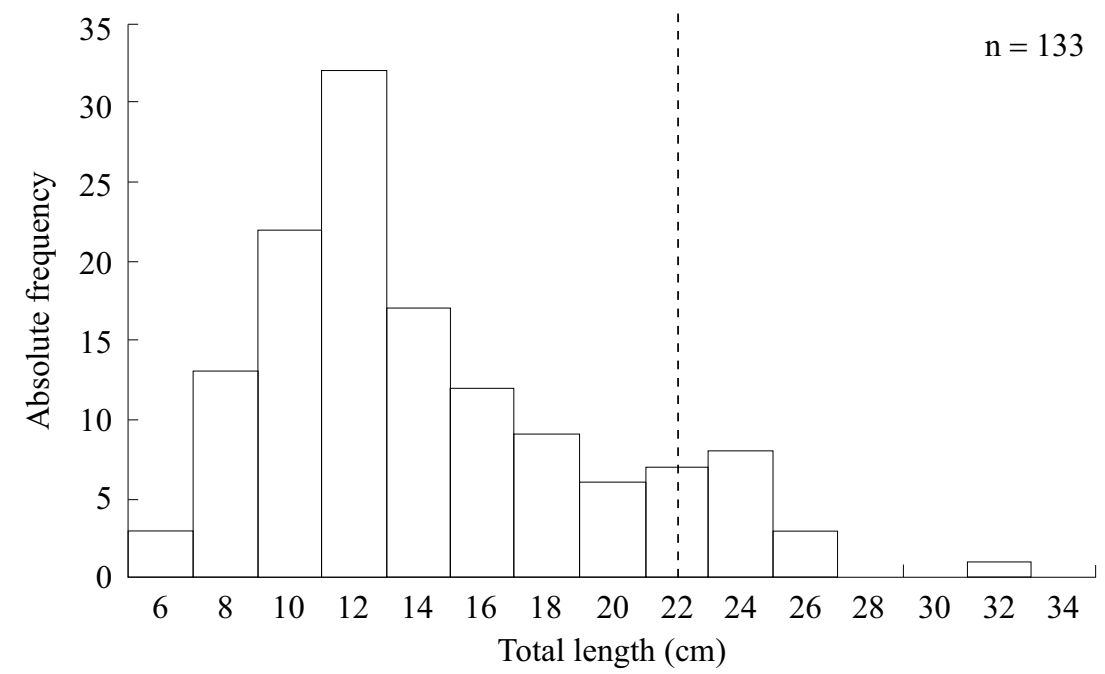

Figure 6. Frequency distribution of total length for Polydactylus virginicus caught in competitive fishing events in Ilhéus, southern Bahia (2007-2008). Dashed vertical line indicates mean size at first maturity estimated from Figure 5.

men/women (6), dentists and technicians (4 each), or public servants (3), followed by teachers, accountants, receptionists, desk assistants, lawyers and wall painters (2 each), and doctor, nurse, unemployed, bank officer, nursing assistant, administrative assistant, and port employee (1 each). Most cited monthly wages were 2-5
(39\%) and 6-10 minimum wages (23\%) (Figure 9). All fishers older than 18 years old had a fishing license, as it was (and still is) a requirement to participate in the CLUPESIL Championship. Younger fishers are not obliged to carry license (unless desiring to have a catch quota), but those older than 65 have to carry the license even 


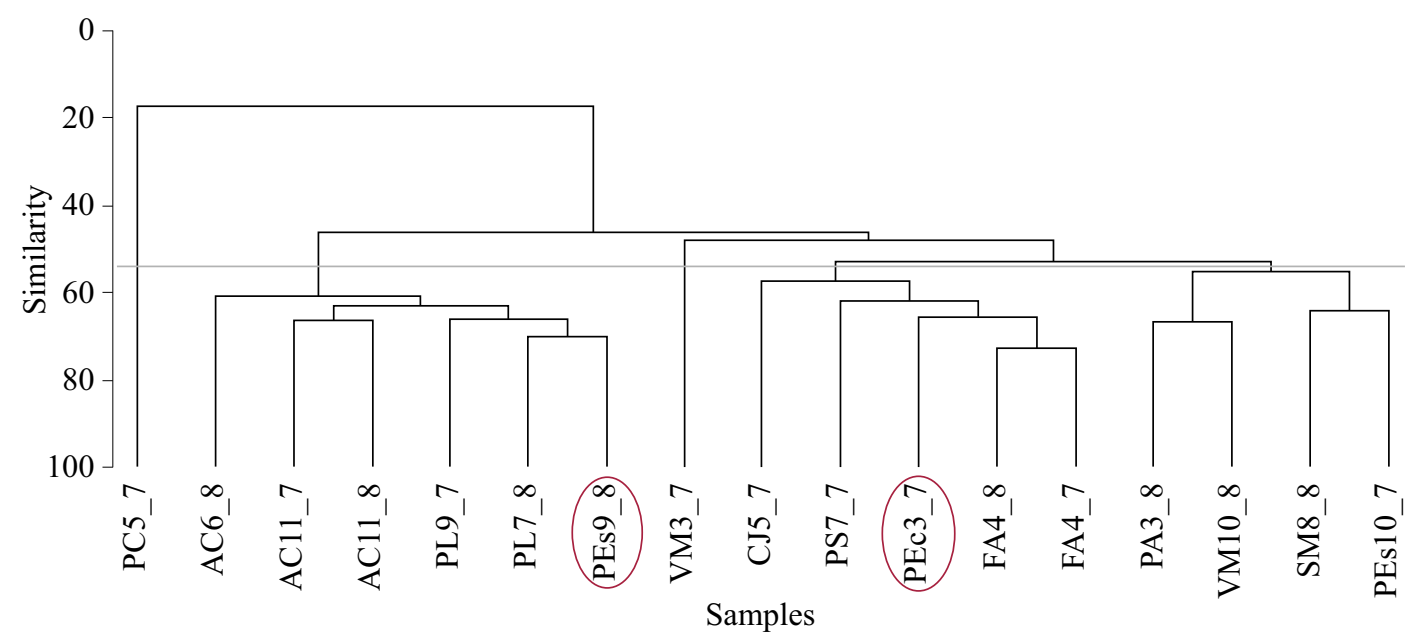

Figure 7. Dendrogram showing similarity of beaches in Ilhéus, southern Bahia, according to their fish species composition (as caught in competitive fishing events in 2007-2008). Letters indicate beaches: PC (Praia do Cristo), PEs (Praia do Espigão), PA (Praia da Avenida), VM (Praia dos Velhos Marinheiros), PS (Pé de Serra), PEc (Pousada Ecológica), FA (Falafina), SM (Praia de São Miguel), PL (Praia de Lencóis), AC (Acuípe), and CJ (Condomínio Japará). First number indicates month and second number, year. Thus: AC11_7 = Acuípe in November 2007. Horizontal continuous line is the cut limit indicating the uniqueness of Praia do Cristo, southern beaches (AC, PL), northern beaches (CJ, PS, FA), and downtown beaches (PA, VM, PEs). São Miguel (SM) is located near downtown beaches and presents similar features in terms of species composition. Ovals indicate outliers.

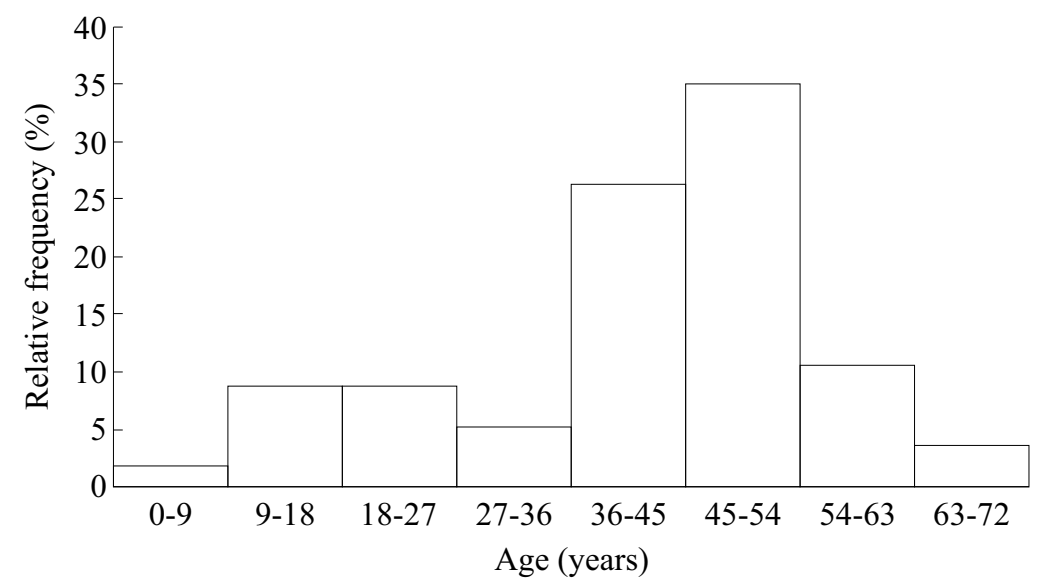

Figure 8. Age of recreational fishers affiliated to CLUPESIL based on 57 questionnaires answered in 2008 (Ilhéus, southern Bahia).

though they do not have to pay for it, according to the national regulation. Most of the fishers enjoyed fishing during both competitive events and outside events $(38 \%)$, followed by those who liked only competitive events $(32 \%)$ or no competitions at all (30\%).
Recreational fishers employed line with mean thickness of $0.26 \mathrm{~mm}(0.10-0.40 \mathrm{~mm})$ during competitive fishing events, which was thinner than the line used outside competitive events (mean $=0.37 \mathrm{~mm} ; 0.10-0.90 \mathrm{~mm})$. Hooks used outside competitive events were also larger in 


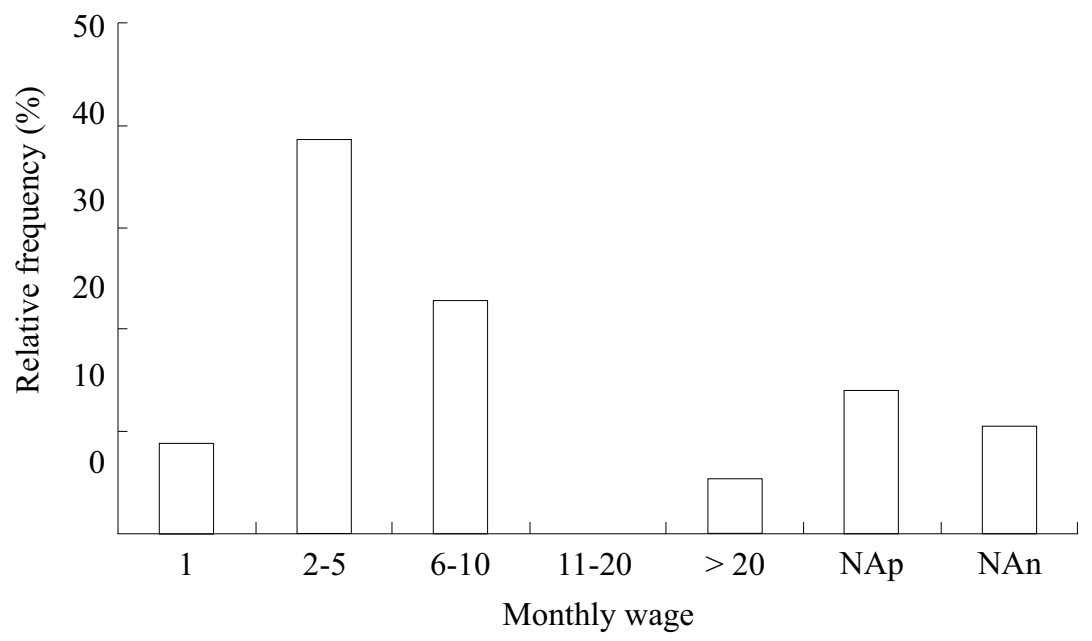

Figure 9. Monthly wage (in number of minimum wages) of recreational fishers affiliated to CLUPESIL based on 57 questionnaires answered in 2008 (NAp = not applicable; NAn = not answered). Minimum wage in 2008: R\$ 415.00 ( $\approx$ USD 226.00).

average, but a wider selection of sizes was used (Figure 10). These results were aligned with the objective of fishers during competitive events: catch many fishes $(55 \%)$, leisure $(31 \%)$, catch large fishes $(11 \%)$, or catch certain species $(3 \%)$. Most of the recreational fishers cited the use of spinning reel (67\%), spinning reel or reel $(23 \%)$, and only reel $(10 \%)$ during fishing activities. The most common bait was shrimp, which was used by $100 \%$ of the interviewed fishers. In addition, ghost shrimp or 'corrupto' (Crustacea, Stomatopoda; $12 \%)$, fish pieces (3\%), and crab 'grauçá', Ocypode quadrata (Fabricius, 1787) (Crustacea, Decapoda; 3\%) were used in different proportions. Several preferred fishing grounds (during competitions or not) were cited by interviewed recreational fishers, but most of them mentioned Acuípe (in the south; 16\%) and southern beaches in general (from Opaba Hotel to Cururupe River; 13\%) (Figure 11). They usually did not show preference for fishing in particular months $(60 \%)$, but preferred to go fishing in the morning (74\%) and during weekends (77\%).

Outside competitive events, a total of $49 \%$ of the interviewed recreational fishers declared eating their catch, $40 \%$ eating or donating it, and
$11 \%$ donating it. In terms of catch-and-release habits, $95 \%$ of them released small fishes, but also catfishes (Ariidae; 9\%), pufferfishes (Tetraodontiformes; 2\%), and A. brasiliensis (2\%). Only a small proportion (2\%) declared not practicing catch-and-release at all. A proportion of $43 \%$ of the interviewed fishers learned how to fish with their father, $21 \%$ with friends, and 15\% were self-taught. The remaining fishers learned either with their husband, brother, grandfather, boss, mother, or father-in-law. However, most of them went fishing mainly with friends (36\%), father $(15 \%)$, son $(12 \%)$, or alone $(12 \%)$, but also with their wife, husband, brother, mother, or family in general.

Recreational fishers had between 0 and 55 years of fishing experience but had been taking part in competitive fishing events for 0 to 34 years (Figure 12). Most of them had 0-10 years of fishing experience at that time (33\%) and the same amount of time taking part in competitive events (58\%). A high proportion of fishers stated that the main existing problem for recreational fisheries was shrimp trawling (49\%; note some fishers mentioned more than one problem), which occurs very close to the coastline and contributes 

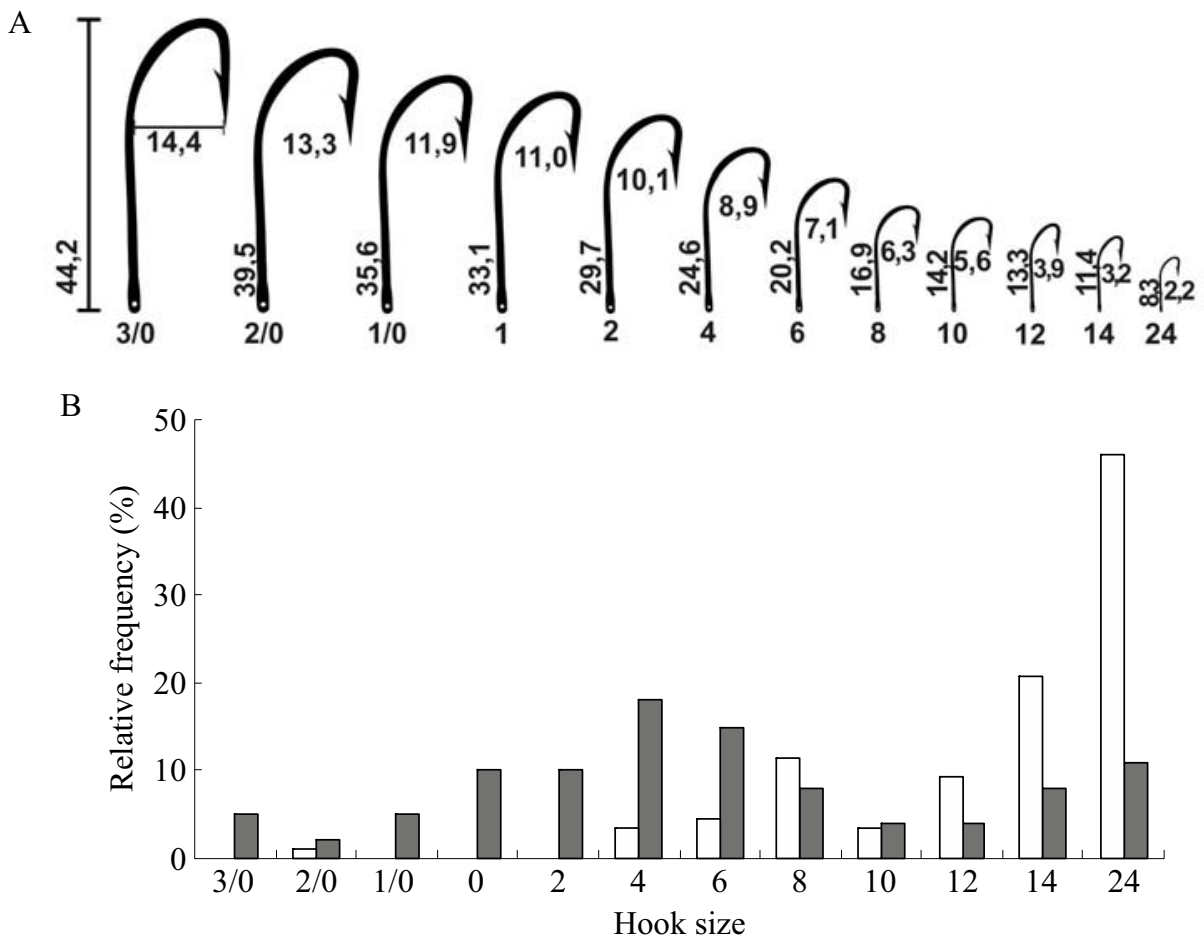

Figure 10. Standard hook size $(\mathrm{mm})$ used during an interview with 57 recreational fishers from CLUPESIL in 2008 (A); hook size that these fishers declared to use during competitive fishing events (white columns) and outside competitive events (gray columns) (B). Each fisher could choose more than one hook size.

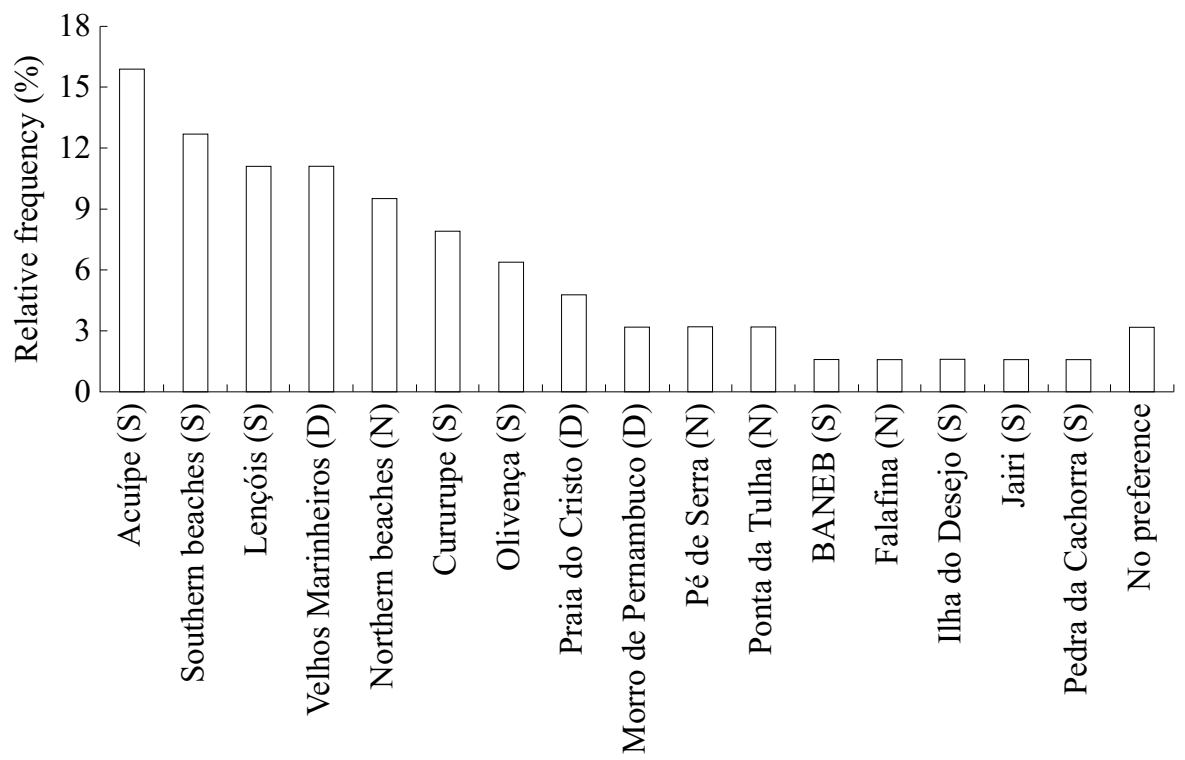

Figure 11. Preferred fishing ground declared by 57 recreational fishers affiliated to CLUPESIL in 2008 (Ilhéus, southern Bahia). $\mathrm{S}, \mathrm{D}$, and $\mathrm{N}$ correspond to southern, downtown, and northern beaches, respectively. 


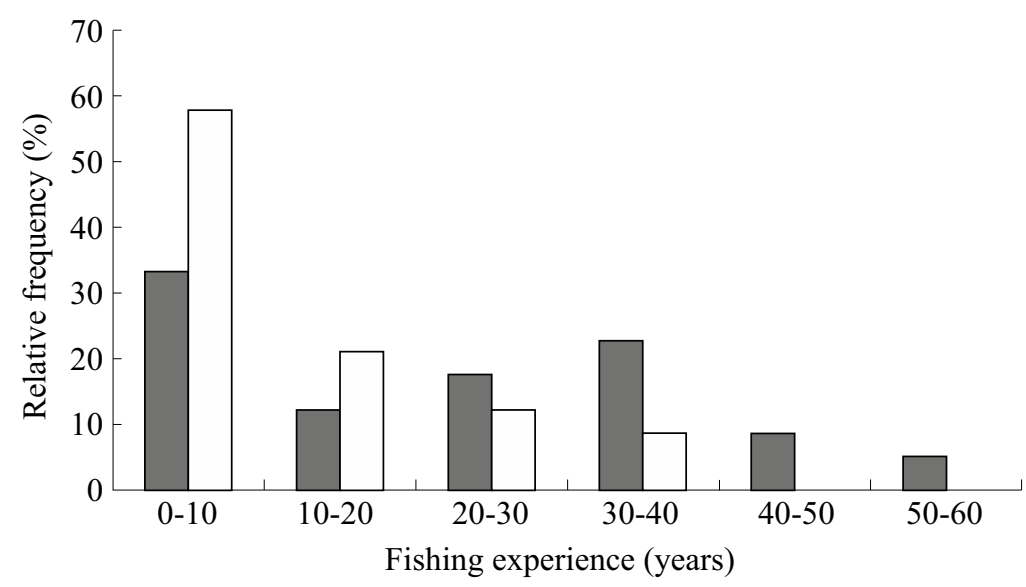

Figure 12. Fishing experience up to 2008 informed by 57 recreational fishers from CLUPESIL (Ilheús, southern Bahia): in general (gray columns) and in competitive fishing events (white columns).

to decreasing fish abundance. On the other hand, $34 \%$ of them did not perceive any problems in recreational fisheries. Other problems mentioned were: pollution $(7 \%)$, capture of small fish $(5 \%)$, and low fish abundance, 'calão' fishery, and retreat of sea level ( $2 \%$ each).

\section{DISCUSSION}

\section{Competitive fishing events and ichthyofauna}

Our study allowed, for the first time, the identification of the catch composition of shorebased fishing competition events in the state of Bahia, indicating a typical surf zone ichthyofauna. The 47 species caught in competitive events in Ilhéus represent a much higher number than the 28 species reported by Freire et al. (2017) for the state of Sergipe, the only known published study that analyzed the species composition of shore-based competitive events in northeastern Brazil. This follows the general fish species composition along the coast of these states as presented by Froese and Pauly (2019), with higher diversity reported for the state of Bahia than for Sergipe. No reports of detailed species composition for onshore competitive events in higher latitudes of Brazil were found. However, for Argentina, one can notice an even lower number of species caught (12 species) as expected, with Cynoscion guatucupa (Cuvier, 1830) and Micropogonias furnieri (Desmarest, 1823) accounting for $80 \%$ of the catch (Llompart et al. 2012). These two species are also caught by recreational fishers during onshore daily fishing activities in southern Brazil (Peres and Klippel 2005), together with at least nine other species that are also caught in Ilhéus (M. littoralis, $G$. genidens, A. brasiliensis, Harengula clupeola (Cuvier, 1829), Centropomus undecimalis (Bloch, 1792), Caranx crysos (Mitchill, 1815), T. goodei, Paralonchurus brasiliensis (Steindachner, 1875), and Stellifer rastrifer (Jordan, 1889). There is also overlapping between species/genera caught in competitive events onshore in Ilhéus (shore-based) and in Guaratuba Bay (boat-based): Larimus breviceps Cuvier, 1830, Genyatremus luteus (Bloch, 1790), Diplectrum spp., Menticirrhus spp., Stellifer spp., Eucinostomus spp., Selene spp., Centropomus spp., Oligoplites spp., and Caranx spp. (Henke and Chaves 2017). Considering that many of these species are also caught in commercial fisheries, it would be important to start 
reporting recreational catches together with commercial catches in national bulletins.

Many factors could have led to the formation of three groups of beaches in the cluster analysis performed here based on their catch composition (north, south, and downtown). Praia do Espigão, Praia da Avenida, and Praia dos Milionários are three beaches representing a continuum located downtown and, as such, were expected to have similar catch composition. This area has been experiencing retreat of the sea level and expansion of the coastal line after the construction of the Malhado Port finalized in 1971 (Franco et al. 2006). In this region, the direction of the longshore drift is northwards. Retreat of the sea level was one of the reasons for concern stated by one of the fishers interviewed. Praia de São Miguel was also included in this group. Even though this beach is not part of this continuum, being located northwards from Malhado Port, it was included in the downtown group. In this specific area, the longshore drift is reversed, flowing southwards (Nascimento et al. 2007), which could explain the similarity in catch composition between Praia de São Miguel and downtown beaches. This region has also suffered strong erosion after the construction of Malhado Port, and this process continues even after the installation of groins (Nascimento and Lavenère-Wanderley 2006). The discharge of Almada and Cachoeira rivers may contribute to differences in catch composition in the north and south, in relation to the downtown area, as these are the two main rivers occurring in the region (Moraes et al. 2009). However, no study was found on local abundance of fish species in such low depth zones as studied here. Moraes et al. (2009) analysed the local demersal fish composition between 10 and $20 \mathrm{~m}$ isobaths. About $50 \%$ of species found in these lower depth zones were also found in their study, with four of them included in their list of the top fourteen most abundant species: $P$. virginicus, $P$. brasiliensis, Chilomycterus spinosus (Linnaeus, 1758), and $L$. breviceps.
One commonality between competitive fishing events in Ilhéus (southern Bahia) and Sergipe is the presence of one species of catfish, along with $M$. littoralis and $P$. virginicus in the list of the most abundant species in the catch. However, catfish species differed between states, with C. spixii dominating in southern Bahia and Sciades proops (Valenciennes, 1840) in Sergipe. Indeed, Marceniuk (2005) reported the occurrence of $C$. spixii along the Brazilian coast down to the state of Paraná, but $S$. proops only down to the state of Pernambuco. Freire et al. (2017) extended its occurrence southwards to the state of Sergipe, but this species does not seem to occur in Bahia. Comparison with competitive fishing events in other areas in the state of Bahia is not possible as catches are not reported by species, but only total catch in number and weight. However, reports from commercial catches for the central coast of Bahia indicated the presence of C. spixii, but not S. proops (Soares et al. 2009).

In relation to $M$. littoralis and $P$. virginicus, it was observed that specimens caught during shorebased competitive fishing events in the state of Bahia were smaller than those caught in Sergipe, with a much higher proportion of immature specimens. Some of the members of the CLUPESIL were aware of this issue and had been discussing the possibility of setting a minimum fish size. This was finally set in March 2014 at $15 \mathrm{~cm}$ (Vilma Souza, CLUPESIL, pers. comm.). However, a minimum size of $15 \mathrm{~cm}$ would still result in a large proportion of immature specimens. The fishing club ASPA-BV (Associação de Pesca Amadora Bons Ventos) in the state of Sergipe has been adopting a minimum size since 2008 , but it kept alternating between 15 and $20 \mathrm{~cm}$ throughout the years (Freire et al. 2014). Since 2014, the minimum size in Sergipe has been set at $15 \mathrm{~cm}$ (Rodrigo Melins, ASPA-BV, pers. comm.). Considering that $M$. littoralis and $P$. virginicus are commercially caught in both states (ThoméSouza et al. 2014), it is important that a minimum size is properly defined to protect local stocks. 
The high number of small specimens is also reflected in the general results presented, with a mean weight of $39 \mathrm{~g}$ per fish $(9-80 \mathrm{~g})$. An increasing trend in mean weight of fishes was observed during the period of two years analyzed here but the reason behind this trend is unknown. Freire (2005) found a decreasing trend in the coast of Rio Grande do Norte, but data analyzed comprised 25 years. There, the decreasing trend could indicate the impact of fishing in the region (all types) and other anthropic factors. But here, the study period was too short (2007-2008) to allow for the observation of such impacts. Thus, mean weight should be monitored through time to detect possible impacts after taking into account the effect of introducing a minimum size in 2014, as previously stated. Fishes caught in Ilhéus were much lighter than those caught in competitive events in Sergipe, where mean weight varied from 21 to $918 \mathrm{~g}$ (Freire et al. 2014). Some of the rules of CLUPESIL Championship favored the capture of a large number of small fishes due to the pointing system adopted at that time (each fisher received three points per fish caught or five points for fishes larger than $15 \mathrm{~cm}$, plus one point per $100 \mathrm{~g}$ or fraction above $50 \mathrm{~g}$ ).

Only one ray was caught in Ilhéus during two years of competitive events in opposition to 18 caught in Sergipe during one year (Freire et al 2017). This reduced number may be related to the local low occurrence of rays, as commercial catches for rays in Ilhéus corresponded to only $0.3 \%$ of total catches (CEPENE 2007) when compared to $1.5 \%$ in Sergipe (Thomé-Souza et al. 2014). As the only specimen caught in Ilhéus was not identified to the species level, we were not able to explore this issue further due to the lack of knowledge on the depth distribution of this unknown species. However, considering rays are K-strategists with slow maturation process, reduced progeny and long life cycle, and thus more prone to overfishing, reduced catches of rays are very positive.

\section{Profile of the recreational fishers}

As in other states in Brazil (Basaglia and Vieira 2005; Freire 2005; Chiappani 2006), there was a predominance of men in coastal recreational fisheries in Ilhéus, mainly with ages between 40 and 50. The same pattern was also observed in offshore recreational fisheries in northeastern Brazil (Freire et al. 2018). In terms of wages, they were similar to the coastal recreational fishers in Rio Grande do Sul (Basaglia and Vieira 2005), but much lower than in the state of Sergipe (Freire et al. 2017) and Espírito Santo (Chiappani 2006).

Both in Sergipe and Bahia, fishers tended to use larger hooks when not participating in competitive events. The most striking difference was the tendency of fishers in Sergipe to use larger hooks (Freire et al. 2017) than in southern Bahia, which was reflected in the size of the caught specimens, as seen above. Similarly to Sergipe (Freire et al. 2017), shrimps were the main bait used and a very low proportion of fishers declared using ghost shrimps (Callichirus spp.). Thus, ghost shrimps may be closer to their unexploited status in the region of Sergipe-Bahia (see, e.g., Rosa et al. 2018). In the state of Paraná, on the other hand, there was an intense exploitation of ghost shrimps as bait in recreational fisheries (Souza and Borzone 2003). Even though they were still used in 2017, their participation was much lower than shrimps (Henke and Chaves 2017). In some areas of the state of São Paulo, their exploitation status has already led to the prohibition of their capture as early as 1992 (Pedrucci and Borges 2009). In 2000, Law N. 1792/2000 also prohibited their catch in Itapema (state of Santa Catarina).

The long term experience of recreational fishers affiliated to CLUPESIL of up to 55 years allowed them to point out some of the problems affecting the sector in Ilhéus. Fishers attributed most of the problems to shrimp trawling, a view shared with fishers from the state of Sergipe, together with lack of fishes, which may actually 
be tightly linked to each other (Freire et al. 2017). A large proportion of recreational fishers in Ilhéus stated the habit of releasing small fishes. However, this was not observed during competitive events due to the pointing system that favors the collection of small fishes. A minimum size was established in March 2014, which has probably resulted in an increase of small fish release. In Sergipe, the proportion of catch-and-release is much smaller (Freire et al. 2017), probably associated to the fact that fishers already use larger hooks and have the habit of consuming their catch, as observed in other regions in Brazil (Freire et al. 2016).

As seen here, the profile of recreational fishers in Ilhéus is similar to other regions but some fishing habits in competitive events indicated a tendency towards catching very small fishes. Even though a minimum catch size of $15 \mathrm{~cm}$ was more recently introduced, this may not be enough to protect juveniles of some species of commercial interest. Increasing to $20 \mathrm{~cm}$ may be better suited considering the presence of a large proportion of juveniles from some of the top-ten species caught in competitive events, which are also of commercial interest. This could be accomplished by using larger hooks. The effect of these measures should be closely monitored considering the absence of studies on hook size selectivity and post-release mortality for most of these species, particularly in this region. Events that took place in downtown Ilhéus led to the capture of specimens with the lowest mean individual weight. We suggest that these beaches be removed from the annual circuit.

The information presented here is expected to serve as a baseline to assess changes through time in the catch composition of competitive fishing events in Ilhéus and in the mean size of fishes caught. Many factors could have affected the results presented here, such as local temperature and salinity, time of the day that fishing events took place, and category of these events (with one, two or three participants), but this may require a longer study period for all these variables to be elucidated. We hope this study will trigger future efforts to answer these questions and also to update the profile of recreational fishers on key issues such as license acquisition, catch-and-release habits, changes in hook sizes and baits used, and gender disparity of fishers and their age structure, which could indicate if there is a trend (or not) of younger generations in not getting involved with recreational fishing. Finally, studies on hook size selectivity are strongly encouraged to assess the effect of the minimum size introduced and any proposed changes.

\section{ACKNOWLEDGMENTS}

We would like to thank the Clube de Pesca de Ilhéus (CLUPESIL) and its recreational fishers for allowing access to fishes caught in competitive fishing events, particularly to R. Mendonça and C.J.G. Almeida. M.F. Rhem identified all species caught by common names. R. Melins, V. Souza, and F. Gomes clarified issues related to recreational fisheries in Sergipe and Bahia during the production of this manuscript. L.C. da Rosa prepared the map of the study area. This work was supported by the National Council for the Scientific and Technological Development CNPq (Edital Universal \#478422/2006-7).

\section{REFERENCES}

Arlinghaus R, Aas $\varnothing$, Alós J, Arismendi I, Bower S, Carle S, Czarkowski T, Freire KMF, Hu J, HunT LM, LYACH R, et al. 2020. Global participation in and public attitudes toward recreational fishing: international perspectives and developments. Rev Fish Sci Aquac. 1-38. doi:10.1080/23308249.2020. 1782340 
Basaglia TP, VieIRA JP. 2005. A pesca amadora recreativa de caniço na Praia do Cassino, RS: necessidade de informações ecológicas aliadas à espécie alvo. Braz J Aquat Sci Technol. 9 (1): 25-29.

Braun AS, Fontoura NF. 2004. Reproductive biology of Menticirrhus littoralis in southern Brazil (Actinopterygii: Perciformes: Sciaenidae). Neotrop Ichthyol. 2 (1): 31-36.

[CEPEne] Centro de Pesquisa e Gestão de Recursos Pesqueiros do Litoral NordesTE. 2007. Boletim estatístico da pesca marítima e estuarina do nordeste do Brasil 2005. Tamandaré: Centro de Pesquisa e Gestão de Recursos Pesqueiros do Litoral Nordeste. 79 p.

Chiappani LHB. 2006. Caracterização e avaliação da atividade de pesca amadora na praia de Camburi, Vitória - ES [undergraduate thesis]. Vitória: Departamento de Ecologia e Recursos Naturais, Universidade Federal do Espírito Santo. 50 p.

Cisneros-Montemayor AM, Sumaila UR. 2010. A global estimate of benefits from ecosystem-based marine recreation: potential impacts and implications for management. J Bioecon. 12 (3): 245-268.

COATES D. 1995. Inland capture fisheries and enhancement: status, constraints and prospects for food security, Kyoto, Japan KC/FI/95/TECH/3. Rome: FAO. 82 p.

Coleman FC, Figueira WF, Ueland JS, CrowDER LB. 2004. The impact of United States recreational fisheries on marine fish populations. Science. 305 (5692): 1958-1960.

Cooke SJ, Cowx IG. 2004. The role of recreational fishing in global fish crises. BioScience. 54 (9): 857-859.

[FAO] FoOd AND Agriculture Organization OF THE United NATIONS. 2018. The state of world fisheries and aquaculture 2018 - Meeting the sustainable development goals. Roma: Food and Agriculture Organization. $210 \mathrm{p}$.
Fedler AJ, Ditton RB. 1994. Understanding angler motivations in fisheries management. Fisheries. 19 (4): 6-13.

Figueiredo JL, Menezes NA. 1978. Manual de peixes marinhos do sudeste do Brasil. II. Teleostei (1). São Paulo, Brazil: Museu de Zoologia, Universidade de São Paulo. 110 p.

Figueiredo JL, Menezes NA. 1980. Manual de peixes marinhos do sudeste do Brasil. III. Teleostei (2). São Paulo, Brazil: Museu de Zoologia, Universidade de São Paulo. 90 p.

Figueiredo JL, Menezes NA. 2000. Manual de peixes marinhos do sudeste do Brasil. VI. Teleostei (5). São Paulo, Brazil: Museu de Zoologia, Universidade de São Paulo. 116 p.

Franco GB, LAVENÈre-WANDERLEY AAO, Moreau MS. 2006. Estudo comparativo da batimetria (1941-1976) da Baía do Pontal, em Ilhéus - Bahia. Cam Geogr. 7 (18): 37 46.

FREIRE KMF. 2005. Recreational fisheries of northeastern Brazil: inferences from data provided by anglers. In: KRUSE GH, GALLUCCi VF, Hay DE, Perry RI, Peterman RM, Shirley TC, Spencer PD, Wilson B, WoodBY D, editors. Fisheries assessment and management in data-limited situations. Fairbanks: University of Alaska Fairbanks, Alaska Sea Grant College Program. p. 377-394.

FrEIRE KMF. 2010. Unregulated catches from recreational fisheries off northeastern Brazil. Atlântica. 32 (1): 87-93.

Freire KMF, BELHABIB D, EsPedido JC, Hood L, KLEISNER KM, LAM VWL, Machado ML, Mendonça JT, Meeuwig JJ, Moro PS, et al. 2020. Estimating global catches of marine recreational fisheries. Front Mar Sci. 7 (12): $1-18$.

FreIRE KMF, Bispo MCS, LuZ RMCA. 2014. Competitive marine fishery in the state of Sergipe. Actapesca. 2 (1): 59-72.

Freire KMF, Luz RMCA, SANTos ACG, OliveIRA CS. 2017. Analysis of the onshore competitive recreational fishery in Sergipe. B 
Inst Pesca. 43 (4): 487-501.

Freire KMF, Sumaila UR, Pauly D, Adelino G. 2018. The offshore recreational fisheries of northeastern Brazil. Lat Am J Aquat Res. 46 (4): 765-778.

Freire KMF, Tubino RA, Monteiro-Neto C, Andrade-Tubino MF, Belruss CG, Tomás ARG, Tutui SLS, Castro PMG, MaruyaMA LS, CATella AC, et al. 2016. Brazilian recreational fisheries: current status, challenges and future direction. Fish Manage Ecol. 23: 276-290.

Froese R, Pauly D. 2019. FishBase. Version 12/2019; [accessed 2020 January]. http:// www.fishbase.org.

Gentner B, Lowther A. 2002. Evaluating marine sport fisheries in the USA. In: PITCHER TJ, Hollingworth CE, editors. Recreational fisheries: ecological, economic and social evaluation. Oxford: Blackwell Science Ltd. p. 186-206.

Henke JL, Chaves PTC. 2017. Ictiofauna e pesca amadora no litoral sul do Paraná: estudo de caso sobre capturas e potencial impacto. Braz J Aquat Sci Technol. 21 (1): 37-43.

Kerr SJ, Kamke KK. 2003. Competitive fishing in freshwaters of North America: a survey of Canadian and U.S. Jurisdictions. Fisheries. 28 (3): 26-31.

KREBS CJ. 1999. Ecological methodology. Menlo Park: Benjamin/Cummings. 620 p.

Llompart FM, Colautti DC, Baigún CRM. 2012. Assessment of a major shore-based marine recreational fishery in the southwest Atlantic, Argentina. New Zeal J Mar Fresh. 46 (1): 57-70.

MARCENIUK A. 2005. Chave para identificação das espécies de bagres marinhos (Siluriformes, Ariidae) da costa brasileira. B Inst Pesca. 31 (2): 89-101.

Menezes NA, Figueiredo JL. 1980. Manual de peixes marinhos do sudeste do Brasil. IVTeleostei (3). São Paulo, Brazil: Museu de Zoologia, Universidade de São Paulo. 96 p.
Menezes NA, Figueiredo JL. 1985. Manual de peixes marinhos do sudeste do Brasil. VTeleostei (4). São Paulo, Brazil: Museu de Zoologia, Universidade de São Paulo. 105 p.

Moraes LE, Romero RM, Rocha GRA, Moura RL. 2009. Demersal ichthyofauna of the inner continental shelf off Ilhéus, Bahia, Brazil. Biota Neotrop. 9 (4): 163-168.

Mourato BL, Hazin H, Hazin F, Carvalho F, Amorim AF. 2016. Assessing Atlantic sailfish catch rates based on Brazilian sport fishing tournaments (1996-2014). Bol Inst Pesca. 42: 625-634.

Mourato BL, Malavasi-Bruno CE, DantasAlberto M, Hazin FHV, Pimenta EG, AmoRIM AF. 2019. Bayesian generalized linear models for standardization of white marlin (Kajikia albida) catch rates based on Brazilian sport fishing tournaments (1996-2017) in the Southwestern Atlantic. Collect Vol Sci Pap ICAAT. 76: 59-70.

NAscimento L, Bittencourt ACSP, SAntos AN, Dominguez JML. 2007. Deriva litorânea ao longo da Costa do Cacau, Bahia: repercussões na geomorfologia costeira. Rev Pesq Geo. 34 (2): 45-56.

Nascimento L, LaVenère-Wanderley AAO. 2006. Effect of shore protection structures (groins) on São Miguel Beach, Ilhéus Bahia Brazil. J Coast Res. SI 39: 858-862.

Nunes JACC, Medeiros DV, Reis-Filho JA, SAMPAIO CLS, BARROS F. 2012. Reef fishes captured by recreational spearfishing on reefs of Bahia State, northeast Brazil. Biota Neotrop. 12 (1): 179-185.

Pedrucci ACC, Borges RP. 2009. Determinação de densidade populacional de Callichirus major na Praia de José Menino - Santos e Itararé - São Vicente. Rev Ceciliana. 1 (2): 121-125.

Peres MB, KLIPPel S. 2005. A pesca amadora na costa da plataforma sul. In: VoOREN CM, KLIPPEL S, editors. Ações para a conservação de tubarões e raias no sul do Brasil. Porto 
Alegre: Igaré. p. 200-212.

Rosa LC, Freire KMF, Souza MJM. 2018. Spatial distribution and population dynamics of Callichirus major (Crustacea, Callianassidae) in a tropical sandy beach, northeastern Brazil. Invertebr Biol. 137: 308-318.

SCHRAMm HL JR, ARMSTRONG ML, Funicelli NA, Green DM, Lee DP, Manns RE JR, TAUBERT BD, Waters SJ. 1991. The status of competitive sport fishing in North America. Fisheries. 16 (3): 4-12.

Soares LSH, Salles ACR, Lopez JP, Muto EY, Giannini R. 2009. Pesca e produção pesqueira. In: HATJE V, ANDRADE JB, editors. Baía de Todos os Santos: aspectos oceano- gráficos. Salvador: EDUFBA. p. 157-206. SouZA JRB, Borzone CA. 2003. A extração de corrupto, Callichirus major (Say) (Crustacea Thalassinidea), para uso como isca em praias do litoral do Paraná: as populações exploradas. Rev Bras Zool. 20 (4): 625-630.

Thomé-Souza MJF, Carvalho BLF, Garciov Filho EB, Silva CO, Deda MS, Félix DCF, SANTOS JC. 2014. Estatística pesqueira da costa do estado de Sergipe e extremo norte da Bahia 2013. São Cristóvão: Editora UFS. $108 \mathrm{p}$.

VAZZOLER AEAM. 1996. Biologia da reprodução de peixes teleósteos: teoria e prática. Maringá, Paraná: Nupelia. 169 p. 
